\title{
Implementation of "If Branch" for Identifying Character Values and Learning Design Based on Scientific Approach for Serat Wedhatama
}

\author{
Suyitno $^{1}$, Ida Zulaeha ${ }^{2}$ \\ \{ suyitno.007@students.unnes.ac.id; suyitno@upgris.ac.id ${ }^{1}$, idazulaeha@mail.unnes.ac.id²
}

Universitas Negeri Semarang, Jateng, Indonesia ${ }^{1}$, Universitas Negeri Semarang, Jateng, Indonesia ${ }^{2}$

\begin{abstract}
The topic of this study is based on the fact that Javanese language teachers have difficulty identifying the character values and teach it with a scientific approach. The solution offered in this study is to implement the "if branching" in identifying character values and making effective designs learning by implementing scientific approach. This research uses descriptive naturalistic method by process carried out through inventory and classification of character values using "if branch" formula and compiling scientific learning design. In-depth study found 181 values of national character which included religious $29 \%$, honest $7 \%$, tolerance $1 \%$, discipline $6 \%$, hard work $27 \%$, independent $1 \%$, democracy $4 \%$, respect for achievement $3 \%$, communicative $10 \%$, love for peace $2 \%$, love to read $4 \%$, and responsibility $7 \%$. The conclusion of this study is that Serat Wedhatama is dominant in religious values, hard work, communicative, responsibility, and discipline, with cumulative 79\%. Serat Wedhatama learning with a scientific approach is carried out by observing, questioning, analyzing, trying to produce text, and communicating the text referring to the Serat Wedhatama.
\end{abstract}

Keywords: "if branch", character value, Serat Wedhatama, scientific approach.

\section{Introduction}

The topic of this study is based on the fact that high school Javanese language teachers have difficulty identifying the character values in Serat Wedhatama and how to teach them with a scientific approach. The difficulty occurs because the teacher does not use technology that is easy to identify character values and has not implemented an effective approach in the learning process.

Serat Wedhatama as a Javanese literary work needs to be analyzed in depth such as literature in general. Literary works whose birth comes from human values in turn must contribute to the form of the values of life (Burhanudin 2017). Literary works were created not only to be enjoyed, but also to be understood and taken advantage of in the form of value, mandate, or advice (Suryadi 2017). As a discourse, the Serat Wedhatama whose disclosure uses language needs to be studied scientifically in a framework of critical discourse analysis. In view of critical discourse analysis, language is not something that is autonomous, neutral or value-free in representing a reality. Language is part of social events (Hasanah 2017). One function of language is as a means of communicating with other parties for various purposes (Apriliyani 2016). In this case, the language used in Serat Wedhatama is to convey the message to the reader. 
Research on the values of characters in Serat Wedhatama has been carried out by Wibawa (2013) who concluded that Serat Wedhatama contains noble teachings to build Javanese spiritual practice. Sutarno and Muya Barida (2017) concluded that Serat Wedhatama contains noble values and teachings and can be used as material for guidance and counseling. Pratiwi and Suwanto (2018) suggest that Serat Wedhatama contains behavioral guidance that can be the basis of a strategy for developing local culture-based character education. In another part, Apollo (218) made a conclusion that in the Serat Wedhatama, specifically Kinanthi's pupuh can be used as a torch to lead humans back to their essence, namely manunggaling kawulaGusti.

In the learning process, the right design is needed. A teacher must be prepared in terms of determining the right learning design for students, creative and innovative basic teaching skills, classroom management, adjusting learning to the student environment, limiting problems that arise, and evaluating learning that meets the criteria (Zulaeha 2015). Regarding the evaluation of learning, Wagiran (2015) recommends that teachers should not ignore the ideal concepts and theories of learning evaluation. This needs to be emphasized due to the results of research on negative trends carried out by social science teachers. Musadad (2013) suggested the results of a study which concluded that the learning process built by social science teachers tended to be boring because it prioritized cognitive aspects and memorization. Priority only makes students know about something. This is not constructive because students should be guided to be able to create or do something based on something (Chatib 2012: 74 76). The negative habits above need to be changed in a more advanced direction by dismantling less productive traditions. Kasali (2007: 205), argues that humans who are bound by tradition can be very difficult to change and can reap their own difficulties. Furthermore Kasali (2014: 118) emphasizes that Indonesia needs a growing mentality, positive souls initiating new ways, critical thinking skills against myths, and encouraging, not punishing learning methods that make students confused.

The solution offered in this study is to implement the "if branching" formula in identifying character values contained in Serat Wedhatama and making new designs in Serat Wedhatama learning by implementing a scientific approach. Lewis Dalam (Soegeng 2013) states that character values are positive traits and characteristics. According to Sentanu (2017: 278), characters are inherent in human identity and name. Nationally, the nation's character encompasses religion, honesty, tolerance, discipline, hard work, creative, independent, democratic, curiosity, national spirit, love for the country, respect for achievement, communicative, peace-loving, fond of reading, caring for the environment, caring social, and responsibility (BP3K 2010: 8-10).

This study aims to find a way to use the if branched formula to identify the character values in Serat Wedhatama and formulate a formula in Serat Wedhatama learning based on a scientific approach. Thus, the problems discussed in this study are (1) how to use the if branched formula to identify the character values in Serat Wedhatama; and (2) how is the formula in Serat Wedhatama learning based on the scientific approach.

\section{Methods}

The method used in this study is a naturalistic descriptive method that is naturally describing character values in Serat Wedhatama. The steps taken in this study are: (1) inventory of character values in Serat Wedhatama using the if branched formula in the eczema 
program, (2) classification of inventoried character values, and (3) formulation design of Serat Wedhatama learning based scientific approach.

Within the framework of achieving the research objectives, the text of the text Serat Wedhatama which contains songs (tembang) is analyzed substantively in the character values of the nation. Serat Wedhatama's text which consists of five group songs (pupuh) covering one hundred stanza (pada). The verses in each verse are analyzed by the dominant value, which is the unity of the values in the verse. Furthermore, these values are inventoried, and are classified according to character values categories, then accumulated and assimilated. These steps can be described as follows.

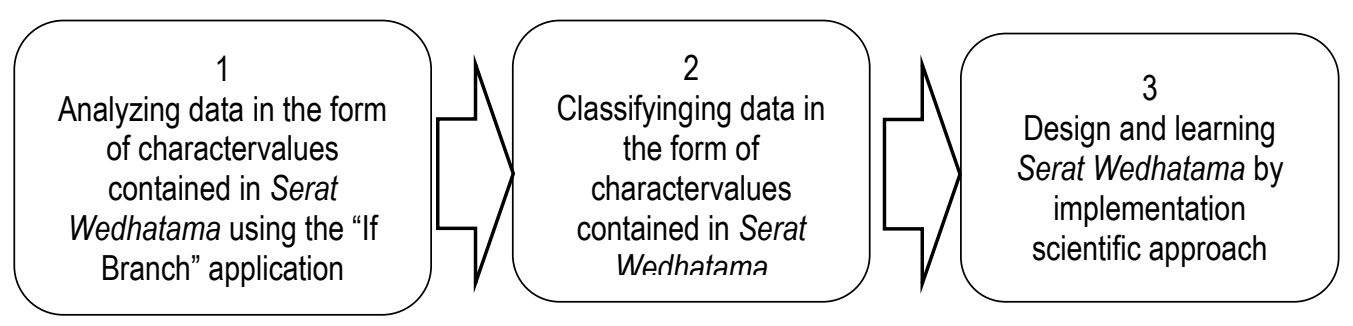

Figure 1. Data analysis steps

\section{Result and Discussion}

\subsection{If Branched" Implementation in Identifying Serat Wedhatama Character Values}

The implementation of the if branch formula to identify character values in Serat Wedhatama is carried out through five stages: (1) compiling a description of the character values in the format of if branch; (2) categorization of character values; (3) internalizing categories into the "if branch" formula; (4) analysis of character values in "if branch"; and (5) classification of character values contained in one hundred stanzas in Serat Wedhatama. The five stages can be described as follows.

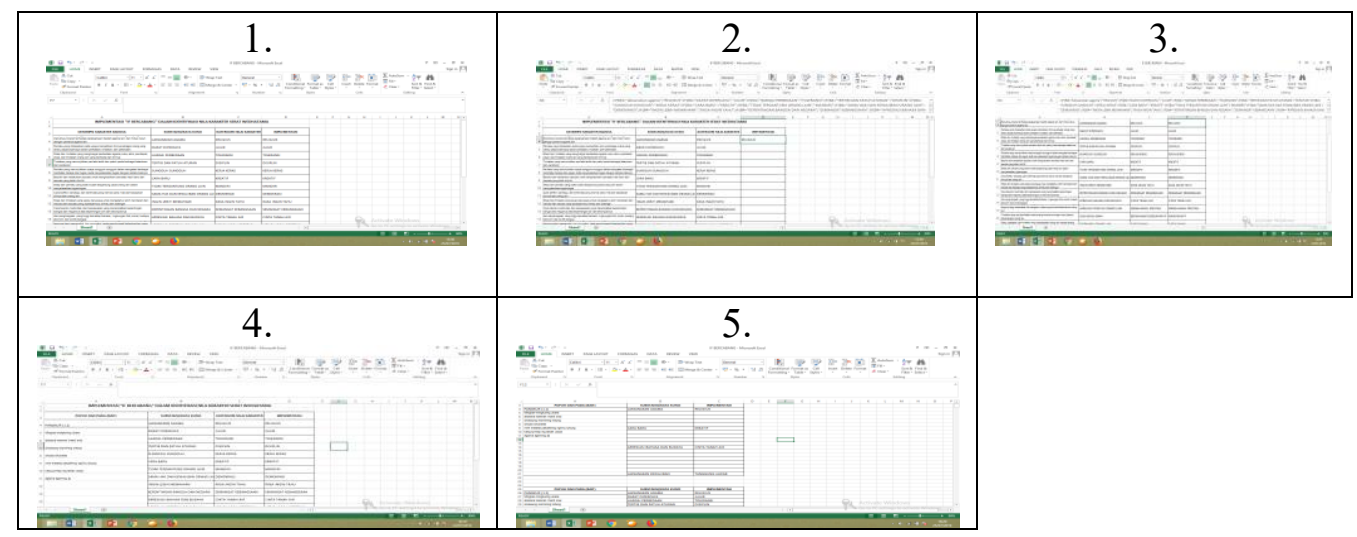

Figure 2. Steps to implement If Branch 
By using the If Branch application it was found 181 character values which included religious $52(29 \%)$, honest $13(7 \%)$, tolerance $1(1 \%)$, discipline $10(6 \%)$, hard work 48 (27\%), independent 2 (1\%), democracy 8 (4\%), respect for achievement 6 (3\%), communicative $18(10 \%)$, love for peace $3(2 \%)$, love to read $7(4 \%)$, and responsibility 13 (7 $\%)$. These results can be seen in the following table.

Table 1. Character values in Serat Wedhatama

\begin{tabular}{lll}
\hline Character Values & Count & Percentaze \\
\hline Religious & 52 & 29 \\
Honest & 13 & 7 \\
Tolerance & 1 & 1 \\
Dicipline & 10 & 6 \\
Hard work & 48 & 27 \\
Independent & 2 & 1 \\
Democracy & 8 & 4 \\
Respect for achievement & 6 & 3 \\
Communicative & 18 & 10 \\
Love for peace & 3 & 2 \\
Love to read & 7 & 4 \\
responsibility & 13 & 7 \\
\hline
\end{tabular}

\subsection{Design of Learning on Serat Wedhatama Based Scientific Approach}

The scientific learning approach includes the activities of observing, asking, analyzing, trying, and forming networks or communicating. The design that can be implemented in Serat Wedhatama learning is through the following steps. First, students are guided to listen to the poetry of the macapat song while reading the text of the song. Second, giving students the opportunity to question words or things that are not yet known. Third, students are guided to analyze the characteristics of the pupuh tembang macapat in Serat Wedhatama. For example; in pupuh Pangkur consists of how many stanzas (tembang); each verse consists of how many lines (gatra); each line consists of what are the syllables (guru wilangan) and what are the prayers (guru lagu); and other characteristics. Fourth, students are guided to compose a type of tembang (Pangkur, Sinom, Pocung, Gambuh, Kinanthi), based on the characteristics (guru gatra, guru wilangan, and guru lagu). Fifth, students are guided to communicate the results of their work (tembang) by singing it in front of the class or writing it beautifully and displayed on a display board

The description of the implementation process of the scientific approach in Serat Wedhatama's learning is as follows. 


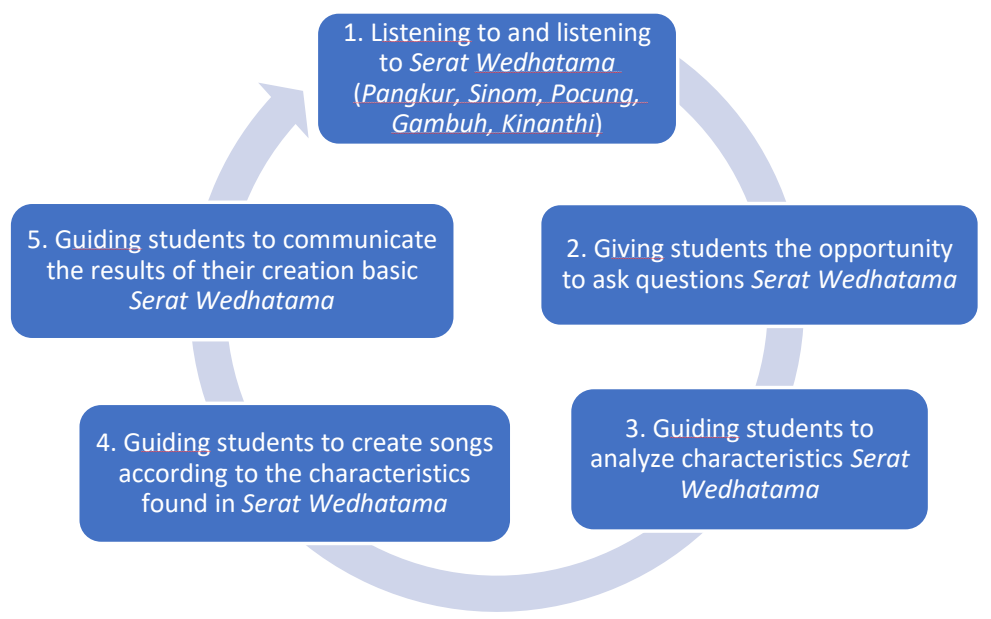

Figure 3. Steps to Implement the Scientific Approach in Serat Wedhatama's Learning

\section{Conclusion}

The conclusion of the results of the analysis and research findings can be formulated as follows. First, in Serat Wedhatama there are twelve types of national characters, namely religious, honest, tolerance, discipline, hard work, independence, democracy, respect for achievement, communicative, peace-loving, like reading, and responsibility. The three most character values are religious character (29\%), hard work character (27\%), and communicative $(10 \%)$; while the lowest three characters are tolerance (1\%), independent $(1 \%)$, and love peace (2\%). Second, the scientific approach is very appropriate to be implemented in Serat Wedhatama's learning. The implementation is carried out by internalizing the songs in Serat Wedhatama in the steps of the scientific approach. 


\section{References}

[1] Apollo. Hermeneutika Serat Wedhatama Kinanthi from https:// www.kompasiana.com/balawadayu, April 17 $7^{\text {th }}$ (2018).

[2] Apriliyani, Nurul and Fathur Rokhman. Strategi Pilihan Bahasa Pengusaha Industri di Kecamatan Ajibarang Kabupaten Banyumas from Seloka: Jurnal Pendidikan Bahasa dan Sastra Indonesia, 5 (2), pp. 184-191 (2016).

[3] Burhanudin, Muhamad. Nilai Humanisme Religius Syiir Pesantren from Jurnal Sastra Indonesia, 6 (1), pp. 35-42 (2017).

[4] Chatib, Munif. Gurunya Manusia. Cetakan VIII. Bandung: Kaifa. (2012).

[5] Dinas Pendidikan dan Kebudayaan Provinsi Jawa Tengah. Kurikulum 2013 Muatan Lokal Bahasa Jawa SMA/SMALB/SMK/MA/MAK Provinsi Jawa Tengah. Semarang (2014).

[6] Hasanah, Alif dan Hari Bakti Mardikantoro. Konstruksi Realitas Seratus Hari Pertama Pemerintahan Jokowi-Jusuf Kalla di Media Online: Analisis Wacana Kritis Model Norman Fairclough from Seloka: Jurnal Pendidikan Bahasa dan Sastra Indonesia, 6 (3), pp. 233-243 (2017).

[7] Kasali, Renald. Re-Code Your Change, Membebaskan Belenggu-Belenggu untuk Meraih Keberanian dan Keberhasilan dalam Pembaharuan. Jakarta: Gramedia Pustaka Utama, (2007).

[8] ........ Let's Change Kepemimpinan, Keberanian, dan Perubahan. Jakarta: Kompas, (2014).

[9] Musadat, Akhmad Arif. Developing Multicultural Education-Based Social Studies Training Model for Teacher's Professional Competencies from The Journal of Education Development, 1 (1), pp. 8-14 (2013).

[10] Nuh, Mohammad. Pengembangan Kurikulum 2013. Jakarta: Kementerian Pendidikan dan Kebudayaan. (2013).

[11] Pratiwi, Pradipta Christy and Yohanes Suwanto. Serat Wedhatama sebagai Salah Satu Warisan Budaya Jawa from https://buletin.k-pin.org/index.php, June 13th 2018.

[12] Pusat Kurikulum. Pengembangan Pendidikan Budaya dan Karakter Bangsa, Pedoman Sekolah. Jakarta: Badan Pendlitian dan Pengembangan, Kementerian Pendidikan Nasional (2010).

[13] Sentanu, Erbe. Kecerdasan Rahasia Manusia Indonesia Karakter 360. Jakarta: Kompas Gramedia. (2017).

[14] Soegeng, A.Y. Nilai-Nilai Pembentuk Karakter dalam Cerita Wayang Purwa. Yogyakarta: Magnum Pustaka Utama (2016).

[15] Soegeng, A.Y., Ghufron Abdullah, R.B. Kasihadi. Landasan Pendidikan Karakter, Cetakan I. Yogyakarta: Magnum Pustaka Utama (2016).

[16] Suryadi, Riza \& Agus Nuryatin. Nilai Pendidikan dalam Antologi Cerpen Senyum Karyamin Karya Ahmad Tohari from Seloka: Jurnal Pendidikan Bahasa dan Sastra Indonesia, 6 (3), pp. 314-322 (2017).

[17] Sutarno, Sutarno and Muya Barida. Kajian Bahan Bimbingan dan Konseling dalam Serat Wedhatama from Jurnal Kajian Bimbingan dan Konseling, 2 (3), pp. 114-122 (2017).

[18] Wagiran, Dandan Supratman, Fathur Rokhman. Comprehensive Evaluation System on Bahasa Indonesia Learning Outcome from The Journal of Education Developmen, 3 (2), pp. 115-124 (2015).

[19] Wibawa, Sutrisna. Filsafat Jawa dalam Serat Wedhatama from Jurnal IKADBUDI, Volume 2 Desember (2013).

[20]Zulaeha, Ida. Innovation Models of Indonesian Learning in Multicultural Society from Procedia - Social and Behavioral Sciences, 103, pp. 506 - 514 (2013).

[21] ......... Model Investigasi Kelompok dengan Teknik Adu Argumen sebagai Upaya Peningkatan Kompetensi Pedagogik Calon Guru Bahasa Indonesia from Jurnal Penelitian Pendidikan, Vol. 32 (1), pp. 25-35 (2015) 